\title{
ANALISIS FAKTOR-FAKTOR YANG MEMPENGARUHI \\ PENGUNGKAPAN CORPORATE SOCIAL RESPONSIBILITY PADA PERUSAHAAN PERTAMBANGAN YANG TERDAFTAR DI BEI
}

\author{
Christine Herawati Limbong \\ Dosen Tetap Sekolah Tinggi Ilmu Ekonomi (STIE) Labuhan Batu \\ Christinehera63@gmail.com
}

\begin{abstract}
ABSTRAK
Tujuan penelitian ini adalah menemukan bukti empiris analisis faktorfaktor yang mempengaruhi pengungkapan Corporate Social Responsibility pada perusahaan pertambangan yang terdaftar di Bursa Efek Indonesia (BEI). Populasi yang akan digunakan dalam penelitian ini adalah semua perusahaan pertambangan yang terdaftar di BEI pada tahun 2014-2017 yang berjumlah 44 perusahaan. Sampel dipilih dengan menggunakan metode purposive sampling berjumlah 32 perusahaan. Data diolah menggunakan metode uji statistik regresi linier berganda. Hasil penelitian ini membuktikan bahwa profitabilitas, leverage, ukuran perusahaan, dan umur perusahaan berpengaruh secara simultan terhadap Corporate Social Responsibility. Secara parsial profitabilitas, ukuran perusahaan, dan umur perusahaan berpengaruh signifikan terhadap corporate social responsibility. Sedangkan leverage tidak berpengaruh signifikan terhadap corporate social responsibility.

Kata kunci : Profitabilitas, Leverage, Ukuran Perusahaan, Umur perusahaan, dan Corporate Social Responsibility.
\end{abstract}

\section{PENDAHULUAN}

Corporate Social Responsibility lahir dari desakan masyarakat atas perilaku perusahaan tersebut di atas yang biasanya mengabaikan tanggung jawab sosialnya terhadap lingkungan dan penduduk sekitar wilayah penambangan (goodcsr.wordpress.com). Corporate Social Responsibility (CSR) sekarang menjadi bagian yang menjadi keharusan dalam perusahaan khususnya yang berbadan hukum perseroan terbatas, dan diatur dalam Undang-Undang No. 40 Tahun 2007 tentang Perseroan Terbatas. Perusahaan yang melakukan pertanggungjawaban terhadap lingkungan sekitarnya, akan berdampak meningkatnya citra perusahaan tersebut. CSR juga merupakan fenomena strategi perusahaan yang terutama dimaksudkan untuk mengakomodasi kebutuhan dan kepentingan stakeholder. Oleh karena itu, diharapkan pemangku kepentingan 
mengetahui informasi yang berkaitan dengan program CSR yang dilakukan oleh perusahaan.

Perusahaan pertambangan merupakan salah satu industri penyumbang terbesar atas kerusakan lingkungan sehingga perlu diadakannya Corporate Social Responsibility sebagai pertanggung jawaban sosial dan lingkungan. Selama lebih dari 50 tahun, konsep dasar pengolahan relatif tidak berubah, yang berubah adalah skala kegiatannya. Mekanisasi peralatan pertambangan telah menyebabkan skala pertambangan semakin membesar. Perkembangan teknologi pengolahan menyebabkan ekstraksi bijih kadar rendah menjadi lebih ekonomis, sehingga semakin luas dan dalam lapisan bumi yang harus di gali. Hal ini menyebabkan kegiatan tambang telah menimbulkan dampak lingkungan yang sangat besar.

Menurut Dirjen Mineral dan Batubara Kementerian ESDM Thamrin Sihite mengatakan bahwa setiap perusahaan tambang menerapkan program tangungjawab sosial (CSR) berupa program yang dapat mengurangi dampak kerusakan lingkungan dari usaha pertambangan. CSR pada pertambangan berbeda dengan CSR pada industri lainnya, seperti perbankan, telekomunikasi, dan sebagainya, karena CSR pertambangan harus sesuai dengan Analisis Masalah dan Dampak Lingkungan (AMDAL) masing-masing perusahaan tambang, yang sudah disetujui oleh pemerintah. Sebagai contoh kerusakan lingkungan yang diakibatkan oleh kegiatan penambangan ada di sekitar area Sleman, Yogyakarta yang menimbulkan kerugian infrastruktur jalan karena merusak sebagian besar jalan kabupaten. Banyak jalan yang rusak karena aktivitas pertambangan, disebabkan oleh muatan angkut yang melebihi batas. Kerugiannya dikalkulasikan dapat bernilai tiga sampai empat kali lipat lebih besar dari pada biaya awal pembangunan jalan. Sedangkan dana pembangunan jalan per tahun mencapai Rp 1,5-Rp 2,5 miliar.

Kerusakan lingkungan juga diakibatkan oleh perusahaan yang termasuk dalam sampel penelitian ialah perusahaan Aneka Tambang, Tbk (ANTM). Dimana pada tahun 2016, aktivitas pertambangan PT Antam di Kabupaten Sarolangun, Jambi dinilai telah mencemari lima sungai besar dan 95 anak sungai di daerah tersebut. Aktivitas tambang PT Antam yang menggunakan bahan kimia berdampak di daerah hilir sungai Kecamatan Batang Asai, Kabupaten Sarolangun. berbagai 
jenis ikan di sepanjang aliran Sungai Mempenau, Sungai Ampar, Sungai Batang Asai, dan Sungai Sako Merah terkena dampak dari aktivitas pertambangan tersebut.

Hal yang sama juga dilakukan oleh perusahaan Energi Mega Persada, Tbk (ENRG). Dimana pada Agustus 2017 telah terjadi kebocoran di salah satu pipa milik perusahaan PT Energi Mega Persada di Kabupaten Kepulauan Meranti. Dinas Kementerian Lingkungan Hidup dan Kehutanan meminta perusahaan bertangung jawab membersihkan limbah, diperkirakan 350 liter minyak mentah tumpah dan mencemari lingkungan. Pada tahun 2014, masyarakat Kabupaten Luwu Timur, melakukan protes terhadap PT Vale Indonesia yang diduga telah mencemari lingkungan dengan tumpahan minyak di Laut Lampia. Ekosistim perairan laut telah rusak karena tumpahan minyak oli jenis hight sulphur fuel oil (HSFO). Bukan hanya di Perairan Lampia, namun juga telah meluas ke perairan lain di sekitar Teluk Bone.

Corporate Social Responsibility juga memiliki standar dan pedoman yang disusun dalam ISO 2600. ISO 26000 merupakan Guidance on social responsibility (panduan tanggung jawab sosial) adalah suatu standar yang memuat panduan perilaku bertanggung jawab sosial bagi organisasi guna berkontribusi terhadap pembangunan berkelanjutan. ISO 26000 merupakan tanggapan ISO terhadap semakin maraknya perhatian dunia terhadap isu tanggung jawab sosial perusahaan. Adanya ketidakseragaman dalam penerapan CSR diberbagai negara menimbulkan adanya kecenderungan yang berbeda dalam proses pelaksanaan CSR itu sendiri di masyarakat. Oleh karena itu diperlukan suatu pedoman umum dalam penerapan CSR di manca negara. Dengan disusunnya ISO 26000 sebagai panduan (guideline) atau dijadikan rujukan utama dalam pembuatan pedoman SR yang berlaku umum, sekaligus menjawab tantangan kebutuhan masyarakat global termasuk Indonesia (isoindonesiacenter.com). Ada 7 isu pokok dalam ISO 26000 yaitu: 1) Pengembangan Masyarakat, 2) Konsumen, 3) Praktek Kegiatan Institusi yang Sehat, 4) Lingkungan, 5) Ketenagakerjaan, 6) Hak asasi manusia, 7) Tata Kelola Perusahaan (Jalal, 2010).

Wibisono (2007) mengungkapkan bahwa ada beberapa manfaat bagi perusahaan yang menerapkan CSR yaitu : Mempertahankan dan mendongkrak 
reputasi dan brand image perusahaan, Mereduksi resiko bisnis perusahaan, Melebarkan akses sumber daya, Membentangkan akses menuju market, Mereduksi biaya, Memperbaiki hubungan dengan stakeholder, Meningkatkan semangat dan produktivitas karyawan, Peluang mendapatkan penghargaan.

\section{Tujuan Penelitian}

Sesuai dengan rumusan masalah, maka tujuan penelitian ini adalah menemukan bukti empiris pengaruh profitabilitas, leverage, ukuran perusahaan dan umur perusahaan secara parsial dan simultan berpengaruh terhadap pengungkapan corporate social responsibility.

\section{Manfaat Teoritis}

Hasil penelitian ini diharapkan dapat dijadikan bahan bacaan bagi peneliti selanjutnya dan meningkatkan perkembangan terhadap teori-teori yang berhubungan dengan penelitian ini.

\section{Manfaat Praktis}

Hasil penelitian ini diharapkan dapat dijadikan sebagai bahan pertimbangan oleh perusahaan untuk menetapkan kebijakan yang konsisten dalam pemberian dan pengungkapan corporate social responsibility dimasa yang akan datang.

\section{TINJAUAN PUSTAKA}

\section{Teori Stakeholder}

Teori Stakeholder merupakan teori yang menyatakan bahwa perusahaan bukanlah entitas yang hanya beroperasi untuk kepentingan sendiri, namun harus memberikan manfaat kepada seluruh stakeholder-nya yaitu pemegang saham, kreditor, konsumen, supplier, pemerintah, masyarakat, analis, dan pihak lain (Chariri, 2007). Kelompok stakeholder inilah yang menjadi bahan pertimbangan bagi manajemen perusahaan dalam mengungkap atau tidak suatu informasi di dalam laporan perusahaan tersebut. Tujuan utama dari teori stakeholder adalah untuk membantu manajemen perusahaan dalam meningkatkan penciptaan nilai 
sebagai dampak dari aktivitas-aktivitas yang dilakukan dan meminimalkan kerugian yang mungkin muncul bagi stakeholder.

\section{Teori keagenan}

Teori keagenan (agency theory) dikembangkan di tahun 1970-an terutama pada tulisan Jensen dan Meckling (1976) pada tulisan yang berjudul "Theory of the firm: Managerial behavior, agency costs, and ownership structure". Jensen dan Meckling (1976) menjelaskan adanya konflik kepentingan dalam hubungan keagenan. Konflik kepentingan ini terjadi dikarenakan perbedaan tujuan dari masing-masing pihak. Adanya perbedaan tujuan antara prinsipal dan agen serta adanya pemisahan antara kepemilikan dan pengendalian perusahaan. Tujuan dari teori agensi adalah pertama, untuk meningkatkan kemampuan individu (baik prinsipal maupun agen) dalam mengevaluasi lingkungan dimana keputusan harus diambil (The belief revision role). Kedua, untuk mengevaluasi hasil dari keputusan yang telah diambil guna mempermudah pengalokasian hasil antara prinsipal dan agen sesuai dengan kontrak kerja (The performance evaluation role).

\section{Pengungkapan Corporate Social Responsibility}

Pengungkapan corporate social responsibility pada laporan tahuan entitas bisnis berdampak positif, yaitu manfaat jangka panjang bagi perusahaan kedepannya. Pengungkapan sosial yang dilakukan oleh perusahaan umumnya bersifat voluntary (sukarela), unaudited (belum diaudit), dan unregulated (tidak dipengaruhi oleh peraturan tertentu).

Sejak tanggal 23 september 2007, pengungkapan tanggung jawab sosial perusahaan (corporate social responsibility disclosure) mulai diwajibkan melalui UU Perseroan Terbatas Nomor 40 tahun 2007, khususnya untuk perusahaanperusahaan yang hidup dari ekstraksi sumber daya alam. Terdapat ketentuan dalam Pasal 66 ayat 2c UU No. 40 tahun 2007, yang menyatakan bahwa semua perseroan wajib untuk melaporkan pelaksanaan tanggung jawab sosial dan lingkungan dalam laporan 18 tahunan. Tidak ada lagi sebutan pengungkapan tanggung jawab sosial 
perusahaan (corporate social responsibility disclosure) yang bersifat sukarela, namun pengungkapan yang wajib hukumnya.

Konsep pelaporan CSR digagas dalam Global Reporting Initiative (GRI). Global Reporting Initiative (GRI) adalah sebuah jaringan berbasis organisasi yang telah mempelopori perkembangan dunia, paling banyak menggunakan kerangka laporan keberlanjutan dan berkomitmen untuk terus-menerus melakukan perbaikan dan penerapan di seluruh dunia (www.globalreporting.org).

Pada tahun 2013, standar GRI memiliki versi terbaru yaitu GRI G-4. Fitur yang ada di GRI G-4 menjadikan pedoman ini lebih mudah digunakan baik bagi pelapor yang berpengalaman dan bagi mereka yang baru dalam pelaporan keberlanjutan sektor apapun dan didukung oleh bahan-bahan dan layanan GRI lainnya (www.globalreporting.org). Dalam standar GRI G-4, indikator kinerja dibagi menjadi tiga komponen utama yaitu ekonomi, lingkungan, dan social dengan total indikator mencapai 91 item. Indikator-indikator yang terdapat di dalam GRI yang digunakan dalam penelitian yaitu :

1. Indikator Kinerja Ekonomi (economic performance indicator)

2. Indikator Kinerja Lingkungan (environment performance indicator)

3. Indikator Kinerja Sosial (social performance indicator)

4. Indikator Kinerja Tenaga Kerja (labor practices performance indicator)

5. Indikator Kinerja Hak Asasi Manusia (human rights performance indicator)

6. Indikator Kinerja Produk (product responsibility performance indicator)

\section{Profitabilitas}

Profitabilitas menurut Kasmir (2010) "merupakan rasio untuk menilai kemampuan perusahaan dalam mencari keuntungan". Rasio profitabilitas merupakan rasio yang bertujuan untuk mengetahui kemampuan perusahaan dalam menghasilkan laba selama periode tertentu dan juga memberikan gambaran tentang tingkat efektifitas manajemen dalam melaksanakan kegiatan operasinya. Efektifitas manajemen disini dilihat dari laba yang dihasilkan terhadap penjualan dan investasi perusahaan. Rasio profitabilitas dalam penelitian ini diwakili oleh return on asset (ROA). 


\section{Leverage}

Perusahaan yang mempunyai proporsi hutang lebih besar, maka perusahaan dengan leverage yang tinggi mempunyai kewajiban lebih untuk memenuhi kebutuhan informasi krediturnya (Indriani, 2011). Teori keagenan memprediksi bahwa perusahaan dengan rasio leverage yang lebih tinggi akan mengungkapkan lebih banyak informasi, karena biaya keagenan perusahaan dengan struktur modal seperti itu lebih tinggi. Pada penelitian ini variabel leverage menggunakan DER (Debt Equity Ratio).

\section{Ukuran Perusahaan}

Besar kecilnya perusahaan dilihat dari besarnya nilai equity, nilai penjualan atau nilai aktiva (Riyanto, 2012). Semakin besar total aktiva, penjualan, log size, nilai pasar saham, dan kapitalisasi pasar maka semakin besar pula ukuran perusahaan tersebut. Pada dasarnya ukuran perusahaan hanya terbagi dalam tiga kategori yaitu perusahaan besar (large firm), perusahaan menengah (medium-size), dan perusahaan kecil (small firm).

Dalam UU No. 20 Tahun 2008 mengklasifikasikan ukuran perusahaan ke dalam 4 kategori yaitu usaha mikro, usaha kecil, usaha menengah, dan usaha besar. Menurut Suwito dan Herawaty (2005), ukuran perusahaan pada dasarnya adalah pengelompokan perusahaan kedalam beberapa kelompok, diantaranya perusahaan besar, sedang dan kecil. Skala perusahaan merupakan ukuran yang dipakai untuk mencerminkan besar kecilnya perusahaan yang didasarkan kepada total aset perusahaan.

\section{Umur Perusahaan}

Umur perusahaan menunjukkan perusahaan tetap eksis, mampu bersaing dan memanfaatkan peluang bisnis dalam suatu perekonomian (Istanti, 2009). Dengan mengetahui umur perusahaan menjadi bahan pertimbangan dalam menanamkan modalnya dengan melihat umur perusahaan, dan dapat diketahui pula sejauh mana perusahaan tersebut dapat survive dimasa depan. Semakin lama sebuah perusahaan berdiri, tentunya telah banyak pula mengalami lika-liku dalam berbisnis, mulai dari kemajuan hingga masalah dan kendala yang dihadapi. 
Kemampuan sebuah perusahaan untuk menyelesaikan berbagai masalah yang muncul dalam masa pengelolaan perusahaan, akan semakin menguatkan keberadaan perusahaan itu sendiri.

\section{Penelitian Terdahulu}

Berbagai penelitian mengenai pengungkapan corporate social responsibility telah dilakukan. Namun, masih sedikit penelitian yang meneliti tentang pengungkapan CSR yang dilakukan di perusahaan pertambangan. Alasan dipilihnya perusahaan pertambangan pada penelitian ini adalah karena perusahaan pertambangan merupakan salah satu pilar penting dalam pembangunan ekonomi Indonesia, sekaligus sebagai penyumbang utama pemasukan kas negara.

Silvia (2012) meneliti tentang Pengaruh Kepemilikan Pemerintah Dan Kepemilikan Asing Terhadap Pengungkapan Tanggung Jawab Sosial (Studi Empiris Pada Perusahaan Yang Tercatat Di Bursa Efek Indonesia). Berdasarkan hasil pengujian hipotesis dapat disimpulkan bahwa kepemilikan pemerintah berpengaruh signifikan terhadap pengungkapan tanggung jawab sosial perusahaan, yang artinya bahwa semakin besar tingkat persentase kepemilikan saham pemerintah, maka semakin luas pula pengungkapan aktivitas tanggung jawab sosial perusahaan pada laporan tahunan perusahaan Sedangkan faktor kepemilikan saham asing tidak berpengaruh secara signifikan terhadap pengungkapan tanggung jawab sosial perusahaan, dimana hal ini berarti bahwa besar kecilnya kepemilikan saham asing tidak akan mempengaruhi pengungkapan tanggung jawab sosial yang dilakukan oleh perusahaan.

\section{Kerangka Konseptual}

Kerangka konsep akan menghubungkan secara teoritis antara variabelvariabel penelitian, yaitu antara variabel independen dengan variabel dependen (Sugiono, 2014). Secara ringkas kerangka konseptual pada penelitian ini adalah menjelaskan tentang pengaruh profitabilitas, leverage, ukuran perusahaan, dan umur perusahaan terhadap Corporate Social Responsibility pada pada pertambangan yang terdaftar di BEI periode 2014-2017. 


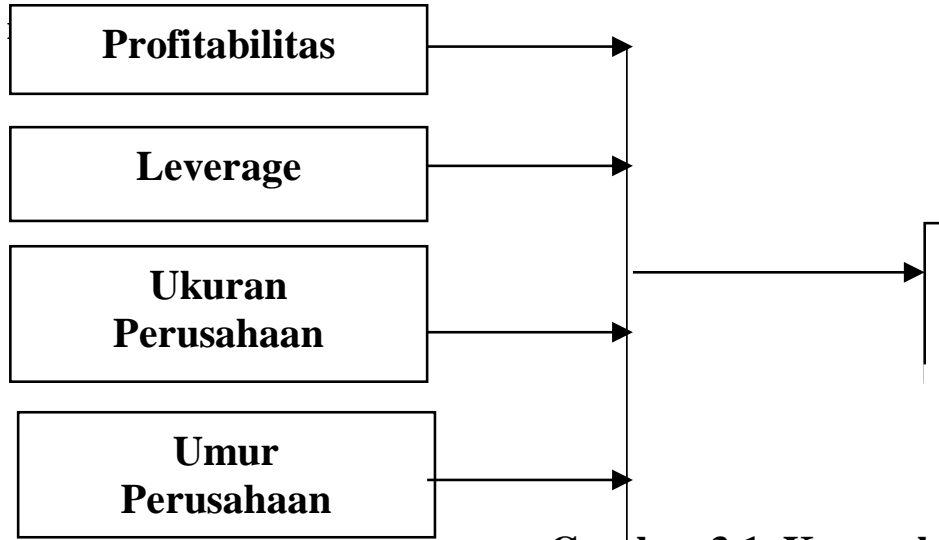

\section{Corporate Social \\ Responsibility}

Variabel Dependen

\section{Hipotesis}

\section{Gambar 3.1. Kerangka Konsep}

Berdasarkan latar belakang teoritis yang sudah dijelaskan diatas, hipotesis dari penelitian ini dapat dijelaskan bahwa profitabilitas, leverage, ukuran perusahaan, dan umur perusahaan secara parsial dan simultan berpengaruh signifikan terhadap corporate social responsibility pada perusahaan pertambangan yang terdaftar di BEI.

\section{METODE PENELITIAN}

\section{Jenis Penelitian}

Penelitian ini merupakan jenis penelitian asosiatif dengan bentuk hubungan kausal. Menurut Sugiyono (2009), asosiatif - kausal adalah "penelitian yang mencari hubungan antara dua variabel atau lebih". Tujuan dari penelitian asosiatif adalah untuk mencari hubungan antara satu variabel dengan variabel lain. Jenis data yang digunakan dalam penelitian ini merupakan data kuantitatif yaitu data yang berbentuk angka atau bilangan yang dapat diolah atau dianalisis menggunakan teknik perhitungan matematika atau statistika. Data yang digunakan merupakan data sekunder, yaitu data sekunder adalah data yang tidak langsung memberikan data kepada peneliti, data ini diperoleh dengan menggunakan studi literatur yang dilakukan terhadap banyak buku dan diperoleh berdasarkan catatan - catatan yang berhubungan dengan penelitian.

Sumber data yang akan diolah dalam analisis penelitian adalah www.idx.co.id, yaitu situs web resmi Bursa Efek Indonesia dimana pada penelitian 
ini data terdiri dari laporan keuangan perusahaan pertambangan yang terdaftar di Bursa Efek Indonesia periode 2014-2017.

\section{Lokasi Penelitian}

Penelitian ini dilakukan pada perusahaan-perusahaan pertambangan yang listing di Bursa Efek Indonesia (BEI) melalui media perantara dengan melakukan browsing pada situs web http://www.bei.co.id.

\section{Populasi dan Sampel}

Menurut Sugiyono (2014) "populasi adalah wilayah generalisasi yang terdiri atas obyek/subyek yang mempunyai kualitas dan karakteristik tertentu yang ditetapkan oleh peneliti untuk dipelajari dan kemudian ditarik kesimpulannya". Jumlah populasi perusahaan pertambangan yang terdaftar di Bursa Efek Indonesia periode 2014-2017 adalah 44 emiten.

Sampel adalah bagian dari jumlah dan karakteristik yang dimiliki oleh populasi (Sugiyono, 2014). Pemilihan sampel dilakukan dengan menggunakan metode purposive sampling yaitu salah satu teknik pengambilan sampel yang dilakukan berdasarkan kriteria atau pertimbangan tertentu. Jumlah sampel pada penelitian ini adalah 32 emiten. Kriteria penentuan sampel adalah sebagai berikut :

1. Perusahaan pertambangan yang listing di BEI pada tahun 2014-2017

2. Perusahaan pertambangan yang telah menerbitkan laporan keuangan yang telah diaudit secara konsisten selama periode pengamatan yaitu pada tahun 2014-2017.

3. Perusahaan menerbitkan laporan tahunan (annual report) lengkap selama tahun 2014-2017. 
Sampel Penelitian Berdasarkan Kriteria

\begin{tabular}{|c|c|c|c|}
\hline No & Kriteria & $\begin{array}{c}\text { Tidak Memenuhi } \\
\text { Kriteria }\end{array}$ & Akumulasi \\
\hline 1 & $\begin{array}{l}\text { Perusahaan pertambangan yang listing di BEI pada } \\
\text { tahun 2014-2017 }\end{array}$ & & 44 \\
\hline 2 & $\begin{array}{l}\text { Perusahaan pertambangan yang telah menerbitkan } \\
\text { laporan keuangan yang telah diaudit secara konsisten } \\
\text { selama periode pengamatan yaitu 2014-2017 }\end{array}$ & 10 & 34 \\
\hline 3 & $\begin{array}{l}\text { Perusahaan pertambangan yang menerbitkan laporan } \\
\text { tahunan atau Annual Report secara konsisten selama } \\
\text { periode pengamatan yaitu 2014-2017 }\end{array}$ & 2 & 32 \\
\hline & \multicolumn{2}{|l|}{ Jumlah Sampel } & 32 \\
\hline & \multicolumn{2}{|l|}{ Tahun Pengamatan (tahun) } & 4 \\
\hline & \multicolumn{2}{|l|}{ Total Pengamatan Selama Periode Penelitian } & 128 \\
\hline
\end{tabular}

\section{Jenis Data dan Metode Pengumpulan Data}

Metode pengumpulan data yang digunakan dalam penelitian ini adalah dengan studi dokumentasi, yaitu dengan cara mengumpulkan data sekunder dari laporan keuangan perusahaan pertambangan yang terpilih menjadi sampel yang telah dipublikasikan oleh Bursa Efek Indonesia (BEI) dan data pendukung lainnya seperti catatan maupun informasi lainnya yang berkaitan dengan penelitian melalui pustaka, media internet dan media massa.

\section{Definisi Operasional dan Metode Pengukuran Variabel}

Variabel tidak bebas dalam penelitian ini adalah corporate social responsibility (Y). Indeks pengungkapan CSR berdasarkan standar GRI (Global Reporting Initiative) yaitu indikator kinerja ekonomi, kinerja lingkungan, kinerja sosial, kinerja tenaga kerja, kinerja hak asasi manusia, kinerja produk. Proksi yang digunakan untuk mengukur pengungkapan CSR adalah CSRI (Corporate Social Responsibility Disclosure Index), dengan rumus penghitungannya adalah sebagai berikut :

$$
\mathrm{CSRI}=\frac{\sum x i j}{n j}
$$

Keterangan:

CSRI : Corporate Social Responsibility Indeks Perusahaan

nj : Jumlah kriteria pengungkapan Corporate Social Responsibility untuk perusahaan, $\mathrm{nj} \leq 91$ 
Xij : Jumlah pengungkapan yang dilakukan perusahaan setiap tahunnya

\section{HASIL DAN PEMBAHASAN}

\section{Uji Signifikansi Pengaruh Simultan (Uji F)}

Uji F bertujuan untuk menguji pengaruh variabel bebas secara bersama-sama atau simultan terhadap variabel tak bebas CSR.

\begin{tabular}{|ll|r|r|r|r|r|}
\hline \multicolumn{1}{|l|}{ Model } & & Sum of Squares & df & Mean Square & F & Sig. \\
\hline 1 & Regression &, 494 & 4 &, 123 & 12,180 &, $000^{\mathrm{a}}$ \\
& Residual &, 922 & 91 &, 010 & & \\
& Total & 1,416 & 95 & & & \\
\hline
\end{tabular}

a. Dependent Variable: CSR (Y)

b. Predictors: (Constant), Umur_Perusahaan (X4), Ukuran_Perusahaan (X3), Profitabilitas (X1), Leverage (X2)

Berdasarkan hasil uji statistik F yang dilakukan dapat dilihat nilai Sig. 0,000 $<0,05$, maka variabel independen yaitu profitabilitas, leverage, ukuran perusahaan, dan umur perusahaan secara simultan berpengaruh positif dan signifikan terhadap corporate social responsibility pada perusahaan pertambangan yang terdaftar di BEI tahun 2014-2017.

\section{Uji Signifikansi Pengaruh Parsial (Uji t)}

Berdasarkan tabel dapat diperoleh persamaan regresi linear berganda sebagai berikut:

$$
\mathrm{Y}=-0,502-0,491 \mathrm{X} 1-0,008 \mathrm{X} 2+0,067 \mathrm{X} 3+0,003 \mathrm{X} 4+\mathrm{e}
$$

Berdasarkan persamaan regresi linear berganda di atas, diketahui:

a. Nilai koefisien dari profitabilitas adalah $-0,491$, yakni bernilai negatif. Nilai tersebut dapat diinterpretasikan profitabilitas berpengaruh negatif terhadap corporate social responsibility. Diketahui nilai Sig 0,039<0,05, maka profitabilitas berpengaruh signifikan terhadap corporate social responsibility. 
b. Nilai koefisien dari leverage adalah $-0,008$, yakni bernilai negatif. Nilai tersebut dapat diinterpretasikan leverage berpengaruh negatif terhadap corporate social responsibility. Diketahui nilai Sig 0,433>0,05, maka leverage tidak berpengaruh signifikan terhadap corporate social responsibility.

c. Nilai koefisien dari ukuran perusahaan adalah 0,067 , yakni bernilai positif. Nilai tersebut dapat diinterpretasikan ukuran perusahaan berpengaruh positif terhadap corporate social responsibility. Diketahui nilai Sig 0,000< 0,05, maka ukuran perusahaan berpengaruh signifikan terhadap corporate social responsibility.

d. Nilai koefisien dari umur perusahaan adalah 0,003, yakni bernilai positif. Nilai tersebut dapat diinterpretasikan umur perusahaan berpengaruh positif terhadap corporate social responsibility. Diketahui nilai Sig 0,000 < 0,05, maka umur perusahaan berpengaruh signifikan terhadap corporate social responsibility.

\section{KESIMPULAN}

Pada penelitian ini membahas bagaimana pengaruh profitabilitas, leverage, ukuran perusahaan, dan umur perusahaan terhadap corporate social responsibility di perusahaan pertambangan di Bursa Efek Indonesia dengan sampel sebanyak 128 perusahaan yang terdaftar. Sesuai hasil analisis data yang dilakukan dapat diperoleh beberapa kesimpulan antara lain :

1. Secara simultan pengaruh profitabilitas, leverage, ukuran perusahaan, umur perusahaan berpengaruh signifikan terhadap corporate social responsibility.

2. Secara parsial profitabilitas berpengaruh terhadap corporate social responsibility. Profitabilitas bernilai negatif. Dimana nilai profitabilitas naik, maka pengungkapan dan pemberian corporate social responsibility ikut meningkat.

3. Secara parsial leverage tidak berpengaruh terhadap corporate social responsibility. Leverage bernilai negatif. Dimana bila nilai leverage naik, maka pemberian corporate social responsibility tidak ikut meningkat. 
4. Secara parsial ukuran perusahaan berpengaruh terhadap corporate social responsibility. Ukuran perusahaan bernilai positif. Dimana jika ukuran perusahaan semakin besar, maka pemberian corporate social responsibility meningkat.

5. Secara parsial umur perusahaan berpengaruh terhadap corporate social responsibility. Umur perusahaan bernilai negatif. Dimana bila umur perusahaan semakin lama, maka pemberian corporate social responsibility juga meningkat.

\section{KETERBATASAN}

Penelitian ini mempunyai keterbatasan-keterbatasan yang dapat dijadikan bahan pertimbangan bagi peneliti berikutnya agar dapat mendapatkan hasil yang lebih baik lagi. Keterbatasan menggunakan sampel yaitu hanya pada perusahaan pertambangan yang terdapat di BEI, sehingga kurang dapat digeneralisasi untuk keseluruhan perusahaan yang terdaftar di Bursa Efek Indonesia.

\section{SARAN}

Berdasarkan kesimpulan dan keterbatasan penelitian yang diuraikan sebelumnya, maka saran dalam penelitian ini adalah:

1. Penelitian ini hanya menggunakan data sekunder laporan keuangan dari industri pertambangan dan belum dapat digeneralisasi. Oleh karena itu peneliti menyarankan agar pada penelitian selanjutnya mengambil objek penelitian yang lebih luas mencakup sektor industri lain.

2. Penelitian selanjutnya diharapkan menggunakan variable moderating untuk dapat memperoleh hasil penelitian yang lebih baik.

\section{Referensi :}

Chariri, Anis. 2011. Stakeholder Theory. Diakses pada tanggal 20 Maret 2016 dari http://staff.undip.ac.id/akuntansi/anis/2011/04/07

Ghozali, Imam. 2016. Aplikasi Analisis Multivariate Dengan Program SPSS. Semarang: Badan Penerbit Universitas Diponegoro

Harahap, Sofyan Syafri. 2013. Analisis Kritis Atas Laporan Keuangan. Cetakan Kesebelas. Penerbit Rajawali Pers. Jakarta. 
Indiriani, Mahtalia, 2011. "Analisis Pengaruh Karakteristik Perusahaan terhadap Pengungkapan Tanggung Jawab Sosial pada Perusahaan Perbankan dan Lembaga Keuangan yang Terdaftar di Bursa Efek Indonesia”, USU, Medan.

Istanti, Lulu Nurul. 2009. “ Pengaruh Harga Saham, Trading Volume Activity dan Risiko Saham Terhadap Bid Ask Spread (Studi Pada Perusahaan LQ45 di Bursa Efek Jakarta)". Jurnal Ekonomi Modernisasi. Vol. 5 No. 3. Malang: Bagian Penerbitan FE-Universitas Kanjuruhan Malang.

Kasmir, 2010. “Pengantar Manajemen Keuangan”, Kencana Prenada Media Group, Jakarta.

Krisna, Aditya Dharmawan dan Novrys Suhardianto. 2016. Faktor- Faktor Yang Mempengaruhi Tanggung Jawab Sosial: Studi Empiris Pada Perusahaan Sektor Pertambangan Yang Terdaftar Di Bursa Efek Indonesia. Jurnal Bisnis dan Akuntansi, Universitas Airlangga Surabaya.

Riyanto, Bambang. 2012. Dasar-Dasar Pembelanjaan Perusahaan (Edisi 4). Yogyakarta: Yayasan Penerbit Gajah Mada

Saidi. 2004. Faktor-faktor yang mempengaruhi struktur modal pada perusahaan manufaktur go public di BEJ Tahun 1997-2002. Dalam Jurnal Bisnis dan Ekonomi, 11(1): 44-58.

Sitepu, Andre Christian dan Hasan Sakti Siregar. 2008. Faktor-Faktor yang Mempengaruhi Pengungkapan Informasi Sosial dalam Laporan Tahunan pada Perusahaan Manufaktur yang Terdaftar di Bursa Efek Jakarta. Jurnal Online. FE USU. Medan.

Suwito, Edy dan Arleen Herawaty. 2005. "Analisis Pengaruh Karakteristik Perusahaan terhadap Tindakan Perataan Laba yang dilakukan oleh Perusahaan yang Terdaftar di Bursa Efek Jakarta". Simposium Nasional Akuntansi VIII Solo. 15-16 September.

Tanudjaja, Bing Bedjo 2006. Perkembangan Corporate Social Responsibility Di Indonesia. Universitas Kristen Petra Surabaya. NIRMANA, VOL.8, NO. 2. Surabaya Tanudjaja, Bing Bedjo 2006. Perkembangan Corporate Social Responsibility Di Indonesia. Universitas Kristen Petra Surabaya. NIRMANA, VOL.8, NO. 2. Surabaya.

Tri Wijayanti dan Muhammad Agung Prabowo. 2011. Pengaruh Corporate Social Responsibility terhadap Kinerja Keuangan Perusahaan. Simposium Nasional Akuntansi XIV. Aceh.

Tuti Rastuti, et al. 2018. Aspek Hukum Pengelolaan Perusahaan. Bandung: Refika.

UU No. 4 Tahun 2009 tentang Pertambangan Mineral dan Batubara

Undang-Undang No. 40 Tahun 2007 Tentang Perseroan Terbatas

Wibisono, Yusuf, 2007. Membedah Konsep dan Aplikasi CSR. Fascho Publishing. Gresik. 